\title{
SISTEME FOTOVOLTAICE COLORATE INTEGRATE ÎN CLĂDIRI BAZATE PE CELULE SOLARE CU COLORANT,I, RESPECTIV CU OXIZI METALICI ${ }^{1}$
}

\section{COLORED BUILDING INTEGRATED PHOTOVOLTAIC SYSTEMS BASED ON DSSC AND METAL OXIDES SOLAR CELLS $S^{2}$}

drd./PhD student Drăgan Florin ${ }^{1}$, prof. dr./prof. PhD. eng. Fara Laurențiu ${ }^{1,2 *}$, prof. dr./prof. PhD. eng. Sterian Paul ${ }^{1,2}$, drd./PhD student Crăciunescu Dan ${ }^{1}$, drd./PhD student Dumitru Constantin ${ }^{1}$

${ }^{1}$ Universitatea Politehnica din București University Politehnica of Bucharest

${ }^{2}$ Academia Oamenilor de Știință din România, București, România Academy of Romanian Scientists, Bucharest, Romania

*lfara@renerg.pub.ro

\footnotetext{
${ }^{1}$ Acest articol este bazat pe proiectul internațional COST MultiscaleSolar MP1406.

${ }^{2}$ The work presented in this article is based on COST MultiscaleSolar MP1406 project.
} 


\title{
Rezumat
}

Sistemele fotovoltaice integrate în clădiri (BIPV) asigură o soluție eficientă din punct de vedere tehnic și economic pentru integrarea celulelor solare în pereții clădirilor, în scopul acumulării energiei solare și producerii de electricitate. Această lucrare ia în calcul îmbunătățirea aspectului estetic al fațadei unei clădiri, precum și obținerea celui mai bun raport între factorul estetic și performanțele tehnice ale celulelor solare. Au fost considerate o serie de materiale pentru celulele solare, care determină diferite culori, după cum este evidențiat și în multitudinea de studii de specialitate. Au fost studiate și comparate două tipuri de celule solare: celulele cu coloranți (DSSC), care reprezintă un tip de celule solare consacrat în domeniu, și celulele solare tandem cu heterojoncțiune și oxizi metalici pe bază de siliciu (STHSC), reprezentând o alternativă promițătoare. Este sugerat un design de module solare multifuncționale, luându-se în considerare atât performanțele lor arhitecturale, cât și cele energetice. Din cauza variației condițiilor de iluminare a clădirii, este considerată abordarea optimă pentru simularea parametrilor de performanță. Un aspect important al studiului îl reprezintă îmbunătăţirea stabilităţii pe termen lung a celulelor, prin încapsulare, cu scopul de a preveni umiditatea și impuritățile. Sunt aduse în discuție foliile, plăcile și ferestrele BIPV, evidențiindu-se o corelare optimă prin combinarea aspectelor estetice cu performanțele celulelor solare implementate.

Cuvinte cheie: BIPV, DSSC, STHSC, aspecte estetice, performanțe arhitecturale, performanțe energetice

\begin{abstract}
Building integrated photovoltaics (BIPV) provide a technically and economically efficient solution for integrating solar cells within building envelopes in order to harvest solar radiation and produce electricity. This work takes into account the improvement of the aestetic aspect of a building's envelope, as well as obtaining the best ratio between aestetic and solar cell performance. There are considered different materials for solar cells, that determine different colors, as it is highlighted in various literature studies. There were studied and compared two types of solar cells: dye-sensitized solar cells (DSSC), which is a consecrated solar cell type used in the field, and Si-based tandem heterojunction metal-oxide solar cells (STHSC), which is a promising alternative. It is suggested a design of mutifunctional solar modules, taking into account both their architectural and energetic performance. Due to variation in building's lighting conditions, the optimum approach is considered for simulation of performancerelated parameters. An important issue of the research is the long-term stability improvement for the cells, through encapsulation, in order to prevent humidity and impurities. There are discusses BIPV foil and tiles, as well as solar cell glazing products, in order to obtain the maximum effect by combining the performance and aestetic aspects of the implemented solar cells.
\end{abstract}

Keywords: BIPV, DSSC, STHSC, aesthetic aspects, architectural performance, energetic performance 


\section{Introducere}

Odată cu creșterea atenției și interesului asupra energiei regenerabile și a eficienței energetice (Fara \& Yamaguchi 2013), clădirile cu zero consum de energie și cu zero emisii de $\mathrm{CO}_{2}$ atrag atenția din ce în ce mai mult. Pentru ca o clădire să atingă aceste standarde, ea trebuie să își acumuleze energia din mediul înconjurător, astfel energia solară fiind alegerea evidentă. Sistemele fotovoltaice integrate în clădiri (BIPV), prin care celule solare sunt integrate în pereții climatici ai clădirilor și utilizează radiație solară pentru a produce electricitate, pot reprezenta un instrument puternic și versatil pentru a atinge aceste scopuri, fiind o soluție estetică, economică și tehnică în același timp. Având ca țintă clădiri cu zero consum de energie, utilizarea energiei solare este necesară pentru a compensa consumul. În clădiri publice și comerciale, o opțiune interesantă este aplicarea de module fotovoltaice semi-transparente pe fațade de sticlă. Celulele cu coloranți (DSSC) oferă oportunităti atractive de design pentru acest gen de aplicații, deoarece culoarea și transparența lor se pot regla prin alegerea moleculelor de colorant absorbant de lumină și prin designul optic folosit în prepararea acestora. Diferite culori și transparențe pot determina multiple elemente estetice.

Autorii prezentei lucrări au avut în vedere analiza a două tipuri de celule solare cu reale perspective de performanță și cost, în speță DSSC și STHSC, pentru a dezvolta sisteme BIPV colorate. Studiul de față va fi orientat către următoarele aspecte:

- înlocuirea materialelor convenționale de construcție cu sisteme BIPV;

- integrarea modulelor fotovoltaice în fațade și acoperișuri;

- îmbunătățirea performanțelor energetice ale clădirilor prin utilizarea unei cantități mai mici de energie electrică convențională;

- îmbunătățirea aspectelor estetice ale clădirilor, prin combinarea de diferite culori;

- studiul unui compromis între performanțele estetice și energetice ale candidaților de celule solare propuse pentru fațade, DSSC și STHSC;

- relația dintre aspectul estetic al clădirilor și culoarea/intensitatea luminii reflectate, respectiv transmise;

- performanțele energetice și electrice sunt în relație atât cu proprietățile electrice ale celulei, cât și cu proprietăţile sale optice (eficiența de conversie, puterea maximă etc.).

Conceptul modelării electro-optice a celulelor studiate este ilustrat în schema din Fig. 1.

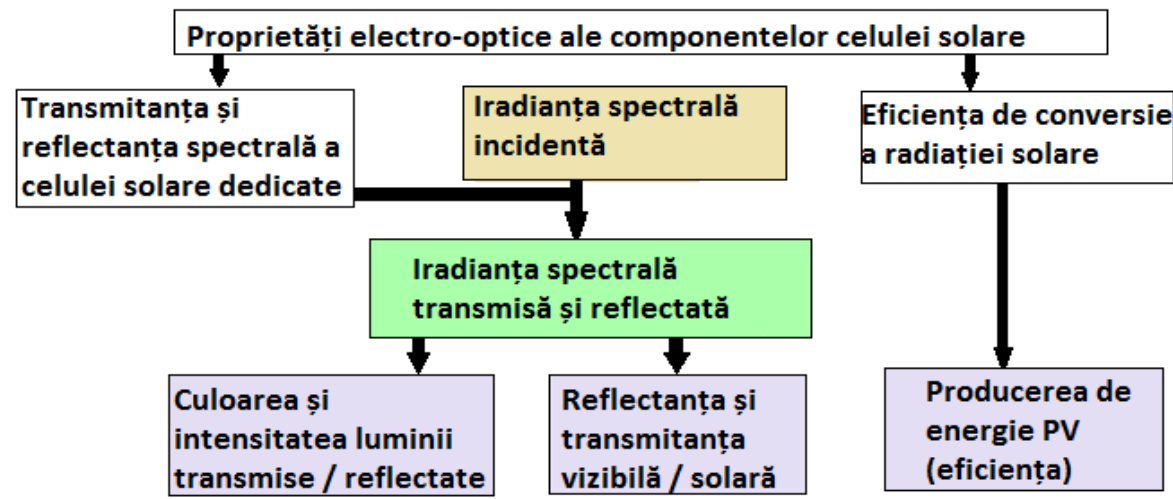

Fig.1. Principiul modelării electro-optice combinate a celulelor solare dedicate, conducând la performanțe energetice și de culoare 


\section{Introduction}

As the world's demand and focus on renewable and non-polluting energy, together with energy efficiency (Fara \& Yamaguchi 2013), are ever increasing, zero energy and zero $\mathrm{CO}_{2}$ emission buildings are rapidly drawing attention. In order for a building to become a zero energy or zero emission one, it needs to harvest energy from its surroundings, where energy from the sun is one of the obvious choices. Building integrated photovoltaic (BIPV) systems, where solar cells are integrated within the climate envelopes of buildings and utilizing solar radiation to produce electricity, may represent a powerful and versatile tool for reaching these goals with respect to both aesthetical, economical and technical solutions. Aiming zero energy buildings requires utilization of solar energy to compensate for their purchased energy consumption. In commercial and public buildings in particular, an interesting option is to apply semi-transparent photovoltaic modules an integral part glass envelopes. Dye-sensitized solar cells (DSSC) offer attractive design opportunities for this application, since their color and transparency are inherently tunable by the choice of the light absorbing dye molecules and optical designs used in their preparation. Different colors and transparencies can make many different aesthetically pleasing results possible.

The authors of the present paper intend to analyze two types of solar cells with real prospects regarding the performance and cost, namely DSSC and STHSC, in order to develop colored BIPV systems. The study will be oriented to the following aspects:

- $\quad$ the conventional building materials will be replaced by BIPV systems;

- integration of photovoltaic modules in facades and roofs;

- $\quad$ through this approach, the energetic performances of the building are improved, by using a smaller amount of conventional electrical power;

- the aesthetic aspects of the building are developed, by using and combining different colors;

- study of a compromise between the aesthetical, optical and electrical performances of some interesting candidates of solar cells for envelopes, namely DSSC and STHSC;

- the aesthetic aspect of the building is related to the color and intensity of reflected light, respectively transmitted;

- the energetic and electrical performances are related both to the electrical and optical properties of the cell (materialized by conversion efficiency, maximum power, etc.).

The concept of this study is highlighted in the schematic diagram from Fig. 1.

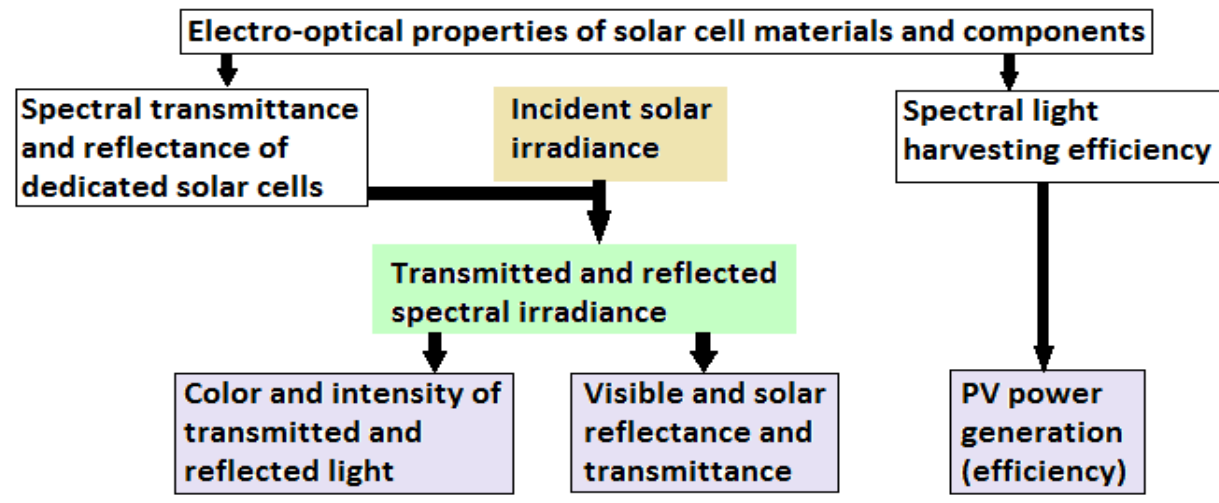

Fig.1: Principle of combined electrical and optical modeling of dedicated solar cells, leading to energetic and color performances 
Principalele contribuții aduse de autori în această lucrare sunt:

- discuții asupra materialelor folosite pentru celule solare, cu implicații asupra performanțelor energetice și estetice;

- analiza critică a celulelor DSSC, respectiv STHSC cu privire la îmbunătățirea performanțelor energetice prin utilizarea diferitelor culori;

- simularea unui studiu de caz: evaluarea parametrilor energetici și a aspectelor estetice pe baza modelării optice a structurii STHSC.

\section{Starea actuală în domeniu}

Sistemele fotovoltaice colorate integrate în clădiri, în special cele bazate pe DSSC, dar nu numai, furnizează o soluție eficientă pentru integrarea celulelor solare în fațadele clădirilor din toate punctele de vedere discutate (tehnic, economic și estetic), acest aspect fiind evidențiat de diferiţi cercetători și contribuțiile lor în domeniu.

Bjørn Petter Jelle rezumă în lucrarea sa "Building Integrated Photovoltaics: A Concise Description of the Current State of the Art and Possible Research Pathways" (Jelle 2016) starea actuală a sistemelor BIPV și propune posibile căi de cercetare pentru BIPV în următorii ani. Janne Halme et. al., de la Universitatea Aalto din Espoo, Finlanda, realizează în lucrarea "Optimizing transparency and performance of semitransparent dye - sensitized solar cells (DSSC) for building façades" (Halme et. al. 2012) o prezentare generală a unei metode experimentale, combinată cu simulare numerică, pentru designul și optimizarea celulelor solare cu coloranți privind elemente de fațadă semitransparente. Folosind această metodă, autorii au dovedit că predictibilitatea culorii, transparenței și eficienței de conversie a celulei DSSC derivă din proprietățile optice ale materialelor și componentelor sale, obținând astfel cel mai bun raport între performanțele estetice, fotovoltaice și de iluminare. Sanghoon Yoon et. al. au investigat în lucrarea "Application of transparent dye-sensitized solar cells to building integrated photovoltaic systems" (Yoon et. al. 2011) relația dintre transparență, eficiența de conversie a celulei DSSC și randamentul total al unei clădiri având un sistem de ferestre cu DSSC. Ei au stabilit, de asemenea, că diferite orientări ale ferestrei în clădire pot afecta condițiile de funcționare optimă ale celulelor cu coloranți.

O serie de studii aprofundate cu privire la proprietăţile fizice și optice ale DSSC merită amintite, cu scopul de a pune în valoare eficiența celulelor cu coloranți în domeniul BIPV.

Janne Halme et. al. au realizat studii aprofundate cu privire la DSSC. În lucrarea "Device Physics of Dye Solar Cells" (Halme et. al. 2010) au prezentat aspectele practice și fundamentale ale modelării și caracterizării celulelor cu coloranți, precum și integrarea acestor cunoștințe într-un model de dispozitiv cu DSSC ușor de utilizat. În articolul "Nanostructured dye solar cells on flexible substrates-Review" (Toivola et. al. 2009), Minna Toivola et. al. au prezentat situația actuală a cercetărilor DSSC nanostructurate cu dioxid de titan pe substraturi alternative de sticlă. Abordări mai exotice precum depunerea structurii DSSC pe fibră optică sau utilizarea nanomaterialelor pe bază de carbon pentru creșterea eficienței celulelor, au fost, de asemenea, discutate în această lucrare. Roberto Tagliaferro et. al., în lucrarea "Interplay between transparency and efficiency in dye sensitized solar cells" (Tagliaferro et. al. 2013), au constatat că relația dintre transparență și eficiență poate fi ghidul general pentru optimizarea DSSC în aplicațiile de integrare a clădirilor.

Faptul că celulele solare tandem cu heterojoncțiune pe bază de siliciu și oxizi metalici (STHSC) reprezintă o alternativă promițătoare în domeniul sistemelor BIPV va fi discutat, de asemenea, în această lucrare.। 
The main contributions brought by the authors in this paper are:

- discussions over the materials used for solar cells, with implications on energy performance and on colors;

- critical analysis of DSSC and STHSC, respectively, regarding improvement of energetic performances and the use of different colors;

- simulation of a case study: evaluation of energetic parameters and aesthetic aspects based on optical simulation of STHSC.

\section{State of the art}

Colored building integrated photovoltaic systems, especially those based on DSSC, provide an efficient solution for integrating solar cells within building envelopes from all discussed points of view (technical, economic and aesthetic), this aspect being proven by various researchers and their contributions in the field.

Bjørn Petter Jelle summarized in his work "Building Integrated Photovoltaics: A Concise Description of the Current State of the Art and Possible Research Pathways" (Jelle 2016) the current state-of-the-art of BIPV systems and addressed possible research ways for BIPV in the next years. Janne Halme et. al., from the Aalto University School of Science, Espoo, Finland, presented in their paper, "Optimizing transparency and performance of semitransparent dye sensitized solar cells (DSC) for building façades" (Halme et. al. 2012) an overview of a combined experimental and computational method for designing and optimizing dye-sensitized solar cell for semitransparent façade elements. Using this method, the authors have proven that color, visible transparency, and photovoltaic efficiency of DSSC are predicted from the optical properties of its materials and components to find the best compromise between aesthetic, daylighting and photovoltaic performance. Sanghoon Yoon et. al. investigated in their work "Application of transparent dye-sensitized solar cells to building integrated photovoltaic systems" (Yoon et. al. 2011) the relationship between the transparency, the efficiency of DSSC and the overall energy efficiency of a building when DSSC is applied as window system. They also found that different orientations of window in the building can affect the optimum conditions of DSSC.

Further studies regarding the physical and optical properties of DSSC worth mentioning, in order to highlight their efficiency in the field.

Janne Halme et. al. performed some further studies regarding DSSC. In the paper "Device Physics of Dye Solar Cells" (Halme et. al. 2010) they presented an overview of the fundamental and practical aspects of the modeling and characterization of DSSCs, and integrating this knowledge into a user-friendly DSSC device model. In the article "Nanostructured dye solar cells on flexible substrates - Review" (Toivola et. al. 2009), Minna Toivola et. al. presented the current state of research on nanostructured titanium dioxide dye solar cells on alternative substrates to glass. More exotic approaches such as depositing the DSSC structure on optical fiber or employing carbon nanomaterials to increase the cell efficiency were also discussed in this paper. Roberto Tagliaferro et. al., in their paper "Interplay between transparency and efficiency in dye sensitized solar cells" (Tagliaferro et. al. 2013), found out that the relation between transparency and efficiency can be the general guide for optimization of DSSC in building integration applications.

The fact that silicon-based tandem heterojunction solar cells (STHSC) represent a promising alternative in the field of BIPV systems will be stressed further in this paper. 
Chin-Yi Tsai and Chin-Yao Tsai au proiectat și dezvoltat cu succes module solare colorate și transparente, de suprafață mare, pe bază de siliciu policristalin în tandem cu straturi subțiri pentru aplicații BIPV, în lucrarea „Development of Tandem Microcrystalline Silicon Thin-Film Large-Area See-Through Color Solar Panels with Reflective Layer and 4-Step Laser Scribing for Building-Integrated Photovoltaic Applications" (Tsai \& Tsai 2014). Ørnulf Nordseth et. al. au demonstrat în lucrarea "Optical Analysis of a $\mathrm{ZnO} / \mathrm{Cu}_{2} \mathrm{O}$ Subcell in a Silicon-Based Tandem Heterojunction Solar Cell” (Nordseth et. al. 2017) că cercetarea celulelor solare tandem cu heterojuncțiune pe bază de siliciu (STHSC) care încorporează oxizi metalici este una dintre principalele direcții de dezvoltare a celulelor solare cu eficiență ridicată. În această lucrare au fost studiate caracteristicile optice ale unei STHSC constând dintr-o subcelulă $\mathrm{ZnO} / \mathrm{Cu}_{2} \mathrm{O}$ dispusă pe o structură de subcelulă pe bază de siliciu.

\section{3. Îmbunătățirea aspectelor estetice și a performanțelor energetice ale}

\section{fațadei unei clădiri}

\subsection{Tehnologia BIPV pentru arhitecți - concepte de bază}

Tehnologia BIPV este o tehnologie în dezvoltare și este încă destul de costisitoare. În plus, se poate observa că sectorul construcțiilor este sensibil la prețuri și, deoarece tehnologia BIPV este încă departe de a fi una matură, incertitudinea cu privire la BIPV și implementarea acestora este un alt aspect crucial care trebuie luat în considerare. Această incertitudine include mulți factori, cum ar fi: instalarea, aspectele electrice, aspectele legate de siguranță, aspectele legate de integrare, protecția împotriva expunerii climatice, durabilitatea, întreținerea, demolarea, evaluarea ciclului de viață și altele. Bineînţeles, toți acești factori pot duce, de asemenea, la creșterea costurilor.

Integrarea celulelor fotovoltaice în clădiri poate fi realizată utilizând acoperișuri înclinate sau plane, fațade și sisteme de umbrire solară. Celulele pot fi montate pe sistemele existente sau tradiționale de acoperiș sau pereți. Pe de altă parte, sistemele BIPV înlocuiesc stratul exterior al pardoselii din clădire, oferind astfel simultan atât un ecran climatic, cât și o sursă generatoare de energie electrică. $\mathrm{Cu}$ alte cuvinte, tehnologia BIPV poate oferi economie de materiale și de muncă, pe lângă reducerea costurilor cu energia electrică. Dat fiind faptul că BIPV acționează ca un ecran pentru protecția mediului înconjurător, este deosebit de important să existe cerințe satisfăcătoare sau stricte de etanșeitate la ploaie și durabilitate. Deși nu fac parte din definiţia BIPV, se pot avea în vedere și modulele BIPV care încorporează părţi mai mari ale fațadei clădirii, cum ar fi, de exemplu, izolarea termică, secțiuni sandwich sau blocuri de construcție.

Mai multe aspecte trebuie luate în considerare și evaluate în ceea ce privește integrarea celulelor fotovoltaice în pereții exteriori ai clădirii. Un aspect îl reprezintă asigurarea unui spațiu de aer sub celulele solare pentru a furniza un flux de aer care să reducă temperatura celulelor solare, deoarece o temperatură ridicată scade eficiența celulelor, în special pentru celulele din siliciu mono și policristalin. Un alt aspect care trebuie luat în considerare este înclinația modulelor BIPV, atât în ceea ce privește clădirile existente, cât și cele noi, deoarece celulele solare trebuie să urmărească înclinarea acoperișului (sau a peretelui, de pildă) ca soluții integrate (pot exista și excepții, în diferite conceptii arhitecturale). Poziția geografică, orientarea spre soare și acoperirea zonei sunt alte aspecte care trebuie luate în considerare în integrarea sistemelor BIPV. De fapt, unii producători BIPV țin cont de toate aceste aspecte pentru a oferi o imagine mai consistentă din punct de vedere estetic a acoperișurilor și fațadelor (a se vedea galeria foto din Fig. 2). 
Chin-Yi Tsai and Chin-Yao Tsai have successfully designed and developed tandem microcrystalline silicon thin-film large-area see-through color solar modules for buildingintegrated photovoltaic applications, in their work „Development of Tandem Microcrystalline Silicon Thin-Film Large-Area See-Through Color Solar Panels with Reflective Layer and 4Step Laser Scribing for Building-Integrated Photovoltaic Applications" (Tsai \& Tsai 2014). Ørnulf Nordseth et. al. have proven in their article "Optical Analysis of a $\mathrm{ZnO} / \mathrm{Cu}_{2} \mathrm{O}$ Subcell in a Silicon-Based Tandem Heterojunction Solar Cell" (Nordseth et. al. 2017) that research on silicon-based tandem heterojunction solar cells (STHSC) incorporating metal oxides is one of the main directions for development of high-efficiency solar cells. In this work, the optical characteristics of a STHSC consisting of a $\mathrm{ZnO} / \mathrm{Cu}_{2} \mathrm{O}$ subcell on top of a silicon-based subcell were studied by optical modeling.

\section{Improvement of the aesthetic aspect and performances of a building's}

\section{envelope}

\subsection{BIPV technology for architects - basic concepts}

The BIPV technology is a growing technology and is still rather expensive. Furthermore, one may note that the building sector is rather price-sensitive. In addition, as BIPV is still far from being a mature technology, uncertainty about BIPV and their implementation is another crucial aspect to be considered. This uncertainty includes many factors, e.g., installation, electrical aspects, safety issues, integration aspects, building physical aspects, protection versus climate exposure, durability, maintenance, demolition, life cycle assessment, possibility to sell surplus electricity to the grid or not, architectural aspects and others. Naturally, all these factors may also lead to increased costs.

Building integration of photovoltaic cells may be carried out on sloped roofs, flat roofs, facades and solar shading systems. PV cells may be mounted above or onto the existing or traditional roofing or wall systems. On the other hand, BIPV systems replace the outer building envelope skin, thus serving simultaneously as both a climate screen and a power source generating electricity. That is, BIPV may provide savings in materials and labor, in addition to reducing the electricity costs. As BIPV act as the exterior climate protection screen, it is of major importance to have satisfactory or strict requirements of rain tightness and durability. Although not part of the BIPV definition, one may also take into account BIPV products incorporating larger parts of the building envelope like including thermal insulation, sandwich sections or building blocks.

Several aspects have to be considered and evaluated related to the integration of the PV cells into the outer building envelope skin. One aspect is to ensure an air gap underneath the solar cells in order to provide an air flow reducing the temperature of the solar cells, as an elevated temperature decreases the efficiency of the solar cells, especially for mono- and polycrystalline Si cells. Another aspect to be considered is the inclination of BIPV, both with respect to existing and new buildings, as the solar cells necessarily need to follow the roof inclination (or the wall for that matter) to be integrated solutions (exceptions may occur in different architectural integrations). Geographical position and orientation towards the sun and area coverage are yet other aspects to be considered during integration of the BIPV systems. In fact, some BIPV manufacturers consider all these aspects in order to provide a more aesthetical and consistent appearance of the roofs and facades (see the gallery from Fig. 2). 


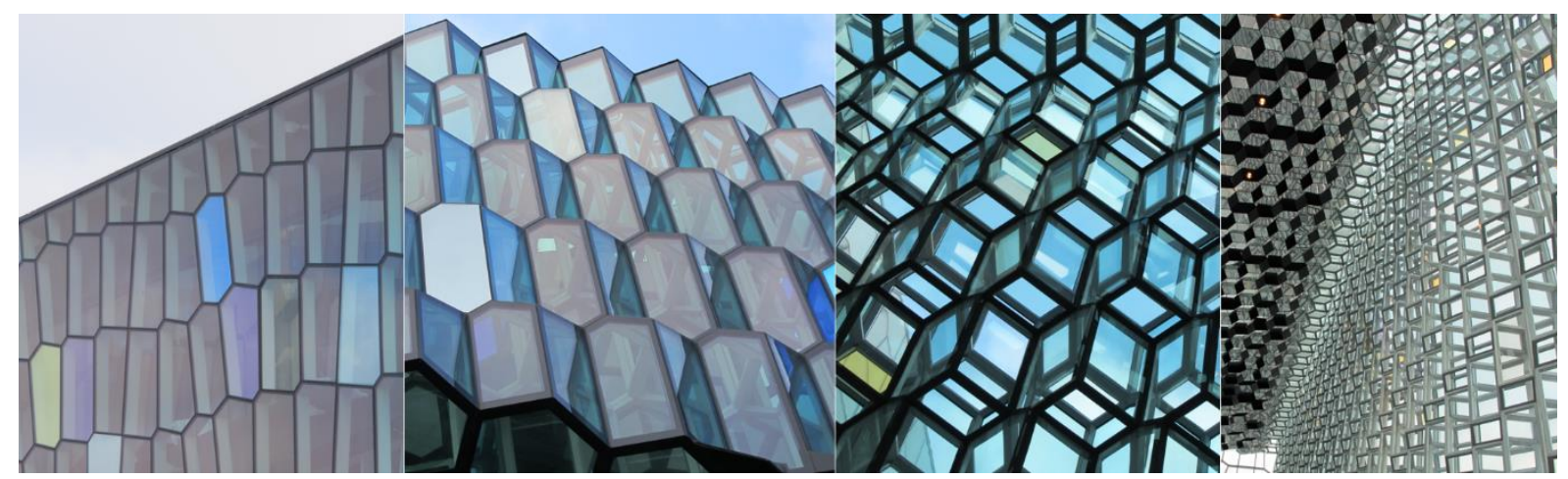

Fig.2: Sala de concerte / centrul de conferințe Harpa în Reykjavík, Islanda Harpa concert hall and conference center in Reykjavík, Iceland

Prin urmare, sistemele BIPV trebuie să îndeplinească toate cerințele în ceea ce privește mai multe proprietăți ale stratului de perete care îl înlocuiesc. De asemenea, trebuie avute în vedere diferite aspecte fizice ale clădirii, cum ar fi transferul căldurii și umidității în peretele clădirii.

Produsele de vitraj cu celule solare oferă o soluție pentru utilizarea fenestrației în ceea ce privește lumina naturală, umbrele solare, diverse expresii arhitecturale și, în final, câștigul de energie solară prin conversia radiației solare în energie electrică.

\subsection{Celule solare colorate: particularități și limitări}

Celulele solare colorate prezintă culori diferite față de albastrul închis standard al celulelor solare tipice. Aceste celule au de obicei o culoare închisă deoarece sunt proiectate să reflecte cât mai puțină lumină posibilă. Astfel, celula solară va produce o putere maximă. Celulele solare monocristaline sunt de obicei albastre, negre sau gri, pe când celulele policristaline sunt de un albastru închis. Culoarea celulelor cu strat subțire de siliciu amorf este întotdeauna aceeași: au o suprafață întunecată cu gri, maro și negru, ca și culori comune. Celulele CIS și celulele cu CdTe sunt întotdeauna întunecate sau negre. Culoarea celulelor solare poate fi schimbată prin modificarea grosimii stratului antireflectător (Sinovoltaics).

\section{3. Îmbunătățirea performanțelor arhitecturale și energetice pe baza celulelor solare cu coloranți}

Celulele solare cu coloranți (DSSC) au de obicei un substrat de dioxid de titan $\left(\mathrm{TiO}_{2}\right)$. Tehnologia este adesea comparată cu fotosinteza și este numită de Grätzel „frunza artificială’1 (Grätzel 1991). Celulele absorb de-a lungul spectrului vizibil și, prin urmare, conduc la o eficiență crescută, de la 7\%, în cazul iradierii solare directe (AM1.5), până la 11\% în lumina difuză a zilei. Materialul $\mathrm{TiO}_{2}$ este un mineral alb, regenerabil și netoxic, oferind astfel un impact mai mic asupra mediului, unde un proces facil de fabricare contribuie la scăderea costurilor. Reducerea costurilor de producție și a impactului asupra mediului au ca rezultat reducerea timpului energetic și economic și, prin urmare, face ca tehnologia să fie foarte promițătoare. Cota de piață pentru această tehnologie este încă foarte mică, dar este de așteptat să crească și poate avea o mare influență în viitor. Structura schematică și mecanismul DSSC sunt prezentate în Fig. 3.

\footnotetext{
1 trad. ns., „the artificial leaf”, Grätzel, M. (1991). The artificial leaf, molecular photovoltaics achieve efficient generation of electricity from sunlight. Coord. Chem. Rev., 111, 167-174
} 


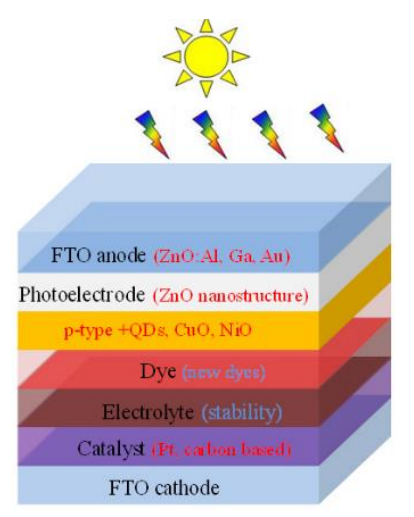

DSSC structure

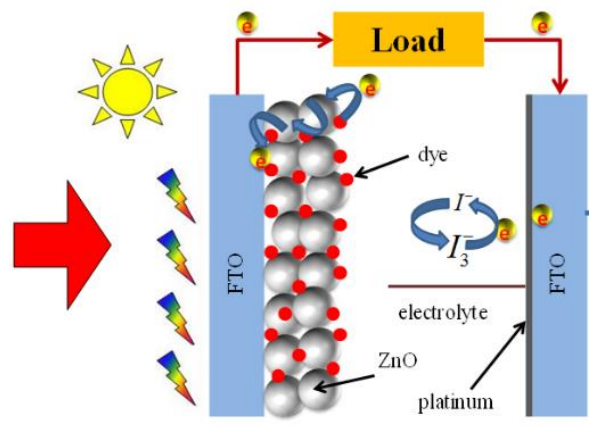

DSSC mechanism

Fig. 3: Schema de principiu și mecanismul DSSC (ThEP)

DSSC schematic structure and mechanism (ThEP)

Hence, in short, BIPV systems have to fulfill all the requirements, with respect to several properties, of the building envelope skins they are substituting. Various building physical issues like heat and moisture transport in the building envelope also have to be considered and accounted for.

Solar cell glazing products offer a solution for utilizing the fenestration with regard to daylight, solar heat gain, solar shading, miscellaneous architectural expressions, and finally solar energy gain by converting solar energy into electricity.

\subsection{Colored Solar Cells: peculiarities and limitations}

Colored solar cells feature different colors than the standard dark grey and bluish colors of typical solar cells. Solar cells usually have a dark color as they are designed to reflect as little light as possible. This way the solar cell will produce maximum power output.

Monocrystalline solar cells are typically blue, black or grey, while polycrystalline solar cells are usually blue or dark blue. The color of thin-film amorphous silicon cells is always the same: it has a dark surface with grey, brown and black as common colors. CIS cells and CdTe cells are always dark brown or black. The color of the solar cells can be changed by varying the thickness of the anti-reflection coating (Sinovoltaics).

\subsection{Improvement of energetic and architectural performance based on DSSC}

Dye sensitized solar cells (DSSC) usually have a titanium dioxide $\left(\mathrm{TiO}_{2}\right)$ substrate material. The technology is often compared with and stated to imitate the photosynthesis, and is by Grätzel called "the artificial leaf" (Grätzel 1991). The cells absorb across the visible spectrum and therefore lead to an increased efficiency ranging from $7 \%$ under direct solar irradiation (AM1.5) and up to $11 \%$ in diffuse daylight. The $\mathrm{TiO}_{2}$ material is a renewable and non-toxic white mineral, thus giving smaller environmental impacts, where an easy manufacturing process contributes to lower costs. The reduced production costs and the decreased environmental impacts result in shorter energy and economical payback time and therefore make the technology very promising. The market share for this technology is still very small, but it is expected to rise and may achieve a great influence in the future. The schematic structure and band diagram for DSSC are depicted in Fig. 3. 
În plus, mulți coloranți sunt sensibili la apă, motiv pentru care încapsularea eficientă este esențială pentru o stabilitate pe termen lung a celulelor, în conformitate cu aplicațiile consumatorilor. Atunci când se integrează celulele DSSC individuale în module PV, stabilirea unor geometrii optime a modulelor, cu scopul de a minimiza pierderile ohmice în contacte și interconectări, este de asemenea importantă pentru optimizarea eficienței modulului.

Arhitecții consideră că modulele DSSC reprezintă o opțiune pentru o clădire în care modulele fotovoltaice semi-transparente încorporate pot crea un mediu interior estetic și confortabil. Pentru a contribui la realizarea iluminatului interior, arhitecții ar putea colabora cu producătorii DSSC pentru a obține celule având o transparență de 30\% în vizibil și a sintetiza o serie de culori corespunzătoare pentru estetica clădirii.

\section{4. Îmbunătățirea performanțelor arhitecturale și energetice pe baza STHSC}

Progresul rapid al celulelor solare cu straturi subțiri au dus la dezvoltarea celulelor solare tandem pe bază de siliciu monocristalin, cu eficiență de conversie dincolo de limita admisă. Astfel de concepte de celule sunt necesare pentru a asigura competitivitatea energiei solare față de energia convențională. În ultimii ani, celulele solare tandem au fost implementate cu succes pentru diferite tehnologii, incluzând celule solare bazate pe semiconductori de tip III-V, celule solare monocristaline, policristaline și amorfe pe bază de siliciu, celule solare cu coloranți și celule solare cu gropi / granule cuantice. Cu toate acestea, fabricarea de celule solare tandem cu heterojuncțione pe bază de siliciu (STHSC) cu o eficiență ridicată, la costuri reduse, nu a fost încă realizată. Această situație ar putea fi schimbată în curând datorită dezvoltării rapide a straturilor subțiri de perovskit ca absorbanți fotovoltaici, cu un progres remarcabil în ultimii 5 ani. Un alt material promițător pentru punerea în aplicare în STHSC este oxidul de cupru $\left(\mathrm{Cu}_{2} \mathrm{O}\right)$. Acest oxid are o absorbție optică ridicată, este netoxic și are un cost potențial redus de producție (Svensson et al., 2013). Limita teoretică a eficienței conversiei pentru o celulă solare bazată pe $\mathrm{Cu}_{2} \mathrm{O}$ este de aproximativ $20 \%$ în condițiile unei singure iluminări solare. Cu toate acestea, cea mai mare eficiență de conversie obținută experimental este de $8,1 \%$ pentru o celulă solară $\mathrm{ZnO} / \mathrm{Cu}_{2} \mathrm{O}$ bazată pe folii de cupru oxidate termic, ceea ce sugerează că este necesară încă o investigație a celulelor solare bazate pe $\mathrm{Cu}_{2} \mathrm{O}$ pentru a fi pus în valoare întregul potenţial al acestora în aplicațiile fotovoltaice.

Fig. 4 prezintă o schemă de principiu a unei celule STHSC, care combină o subcelulă de siliciu cristalin convențional cu o subcelulă $\mathrm{ZnO} / \mathrm{Cu}_{2} \mathrm{O}$ într-o stivă mecanică de celule conectate independent rezultând o configurație cu patru terminale. Diferența de bandă relativ mare dintre $\mathrm{Cu}_{2} \mathrm{O}(\mathrm{Eg}=2,1 \mathrm{eV})$, care este cu aproximativ $1 \mathrm{eV}$ mai mare decât cea a siliciului cristalin $(\mathrm{Eg}=1,13 \mathrm{eV})$, face dificilă realizarea unei configurații tandem monolitice cu costuri reduse. În general, o configurație cu patru terminale permite accesarea unei game mai largi de combinații de materiale comparativ cu o configurație cu două terminale.

Diferite tehnologii inovatoare au fost cercetate, dezvoltate și introduse în linia de producție a modulelor solare colorate și transparente de suprafaţă mare pe bază de siliciu policristalin în tandem cu straturi subțiri pentru aplicații BIPV. Aceste tehnologii noi, utilizând straturi reflectătoare și procedeul de inscripționare cu laser, sunt atât compatibile cu procesele de producție existente, cât și eficiente din punct de vedere al costurilor. Ele au fost introduse cu succes în producția panourilor BIPV de diferite culori: violet, albastru închis, albastru deschis, argintiu, auriu, portocaliu, roșu sau cafeniu. 
In addition to this, many dyes are sensitive to water, which is why efficient encapsulation is crucial to make the long-term stability of the cells realistic to consumer applications. When combining individual DSSCs to modules, finding optimal module geometries to minimize ohmic losses in the contacts and interconnects is also salient to optimize the efficiency of the solar module.

Architects consider DSSC modules as an option to a building where semi-transparent photovoltaic envelopes would match with the interior designs to create aesthetically interesting yet comfortable indoor environment while generating solar electricity. To contribute to and mix with the indoor lighting, the architects would agree with a DSSC manufacturer that the photoactive area of the DSSCs should have 30\% visible transparency and ask them a list of different colors that they could synthesize.

\subsection{Improvement of energetic and architectural performance based on STHSC}

Rapid progress of thin film solar cells has resulted in the development of tandem solar cells based on crystalline silicon with conversion efficiencies beyond the c-Si single-junction limit. Such cell concepts are needed to ensure competitiveness of solar power with conventional energy sources. In recent years, tandem solar cells have been successfully implemented for various technologies, including solar cells based on III-V type semiconductors and monocrystalline, polycrystalline, and amorphous silicon, dye sensitized solar cells, and quantum dot solar cells. However, the manufacturing of silicon- based tandem heterojunction solar cells (STHSC) with a high efficiency at low cost has still not been accomplished. This situation might soon be changed due to the swift development of perovskite thin films as photovoltaic absorbents, showing a remarkable progress in the last 5 years. Another promising material for implementation in STHSC is cuprous oxide $\left(\mathrm{Cu}_{2} \mathrm{O}\right)$. This semiconducting metal oxide has a high optical absorption, is non-toxic, and has the potential for low production cost (Svensson et. al. 2013). The theoretical limit of the conversion efficiency for a solar cell based on $\mathrm{Cu}_{2} \mathrm{O}$ is approximately $20 \%$ under one sun illumination. However, the highest conversion efficiency achieved experimentally is $8.1 \%$ for a $\mathrm{ZnO} / \mathrm{Cu}_{2} \mathrm{O}$ solar cell based on thermally oxidized copper sheets, suggesting that further investigation of $\mathrm{Cu}_{2} \mathrm{O}$-based solar cells is still needed in order to realize their full potential in photovoltaic applications.

Fig. 4 shows a schematic device design of a STHSC, combining a conventional crystalline silicon subcell with a $\mathrm{ZnO} / \mathrm{Cu}_{2} \mathrm{O}$ subcell in a mechanical stack of independently connected cells, i.e . a four-terminal configuration. The relatively high band gap of $\mathrm{Cu}_{2} \mathrm{O}(\mathrm{Eg}$ $=2.1 \mathrm{eV})$, which is approximately $1 \mathrm{eV}$ higher than that of crystalline silicon $(\mathrm{Eg}=1.13 \mathrm{eV})$, makes it challenging to realize a low-cost monolithic (two-terminal) tandem configuration. In general, a four-terminal configuration allows accessing a wider range of material combinations compared to a two-terminal configuration since there is less constraint on current matching for the two subcells.

Many innovative technologies are researched, developed, and introduced into the production line of the large-area tandem microcrystalline silicon thin-film solar module for BIPV applications. These novel and key technologies, including reflective layers and 4-step laser scribing, are not only compatible with the existing manufacture processes but also very cost effective. They were successfully introduced into the production line to manufacture BIPV panels with various colors, such as purple, dark blue, light blue, silver, golden, orange, red wine, and coffee. 


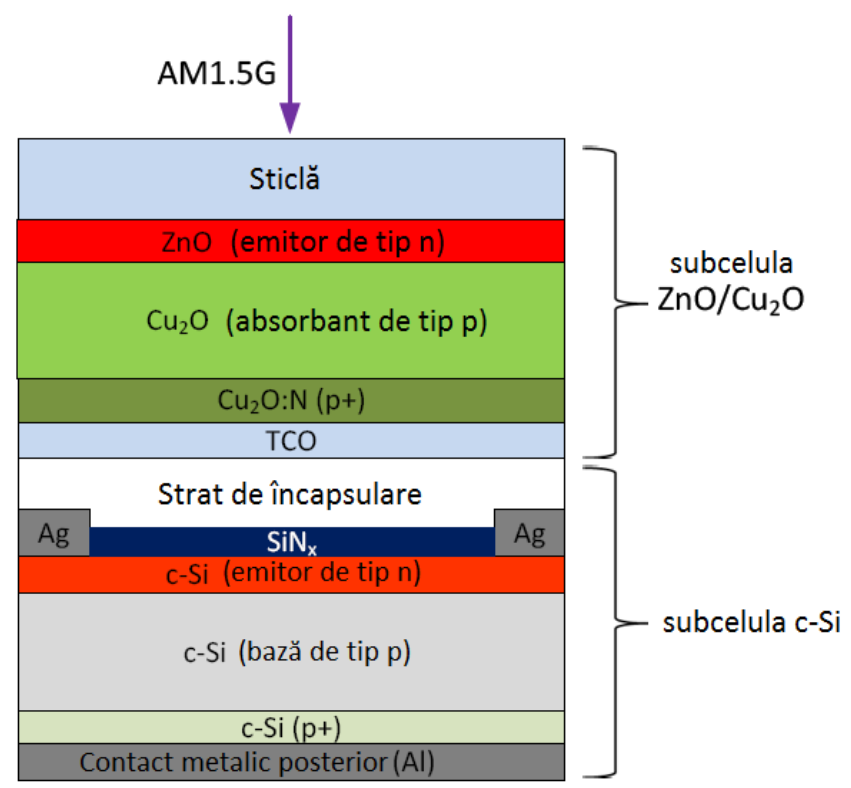

Fig. 4: Schema unei celule solare tandem cu heterojuncțiune cu patru terminale, care combină o subcelulă convenţională pe bază de siliciu cristalin cu o subcelulă cu oxizi metalici bazată pe straturi de $\mathrm{ZnO}$ și $\mathrm{Cu}_{2} \mathrm{O}$ Schematic device design of a four-terminal tandem heterojunction solar cell combining a conventional crystalline silicon bottom subcell with a metal oxide top subcell based on $\mathrm{ZnO}$ and $\mathrm{Cu} 2 \mathrm{O}$ layers.

Structura unei celule obișnuite în modulele solare tandem cu straturi subțiri pe bază de siliciu este prezentată schematic în Fig. 5(a). În general, grosimea straturilor de sticlă (anterior și posterior) este de aproximativ $3,2 \mathrm{~mm}$, stratul reflectător posterior are $0,5 \mathrm{~mm}$, stratul de a$\mathrm{Si}: \mathrm{H}$ are $300 \mathrm{~nm}$, stratul $\mu$-Si are $1400 \mathrm{~nm}$, stratul TCO posterior are $1500 \mathrm{~nm}$ și stratul TCO anterior are $1800 \mathrm{~nm}$. În contrast, structura unui modul BIPV de culoare vizibilă este prezentată schematic în Fig. 5(b), unde stratul reflectător posterior va fi utilizat în scopul de a fi cât mai transparent. În plus, un strat reflectător frontal va fi adăugat pe substratul de sticlă pentru a reflecta o parte din lumina solară și, în consecință, va conferi panoului solar o culoare special proiectată. Grosimea stratului reflectător este, de obicei, de câteva zeci de nanometri, în funcție de specificațiile panourilor colorate proiectate.

\section{Studiu de caz: evaluarea parametrilor energetici și a aspectelor estetice}

\section{pe baza simulării optice a STHSC}

În general, pierderile termice pentru dispozitivul STHSC sunt reduse dacă majoritatea fotonilor cu energie ridicată sunt absorbiți în subcelula superioară și, prin urmare, este avantajos să fie absorbiți cât mai mulți fotoni de energie ridicată în stratul absorbant $\mathrm{Cu}_{2} \mathrm{O}$. Fig. 6(a) prezintă curentul de fotogenerare calculat în funcție de grosime pentru stratul de $\mathrm{Cu}_{2} \mathrm{O}$ (crescut și normalizat) pentru iluminarea AM1.5G. Calculul arată că un strat de $\mathrm{Cu}_{2} \mathrm{O}$ cu grosimea de $2 \mu \mathrm{m}$ va genera aproximativ $10 \mathrm{~mA} / \mathrm{cm}^{2}$ de fotocurent. Aceasta corespunde cu aproximativ $80 \%$ din fluxul de fotocurent care poate fi generat pentru un strat infinit de gros. Figura 6(a) arată că valoarea curentului fotogenerat este mai mică pentru stratul de $\mathrm{Cu}_{2} \mathrm{O}$ normalizat, comparativ cu stratul de $\mathrm{Cu}_{2} \mathrm{O}$ crescut, din cauza unei împrăștieri reduse a granulelor de cristal. Fig. 6(b) prezintă reflectanța, absorptanța și transmitanța normalizate în funcție de lungimea de undă pentru modelul de celulă STHSC prezentat în Fig. 4. În această simulare, un strat AZO frontal cu grosimea de $80 \mathrm{~nm}$, un strat de $\mathrm{Cu}_{2} \mathrm{O}$ de $2 \mu \mathrm{m}$ și un 


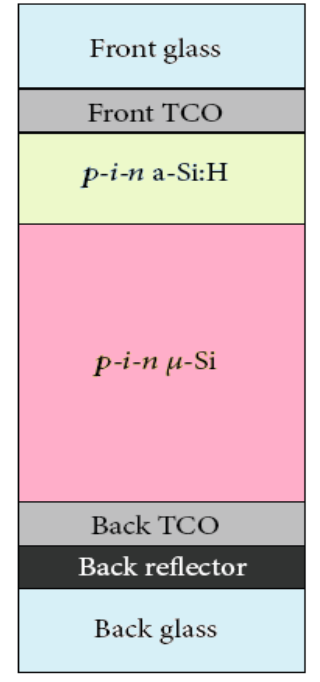

(a)

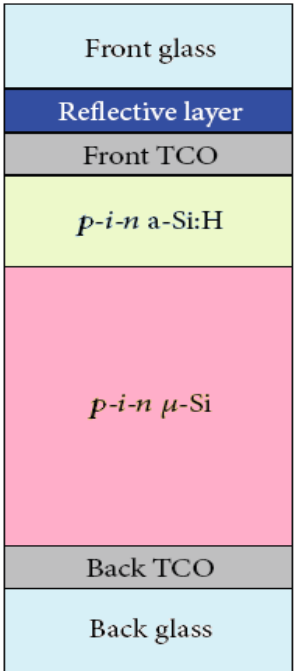

(b)

Fig. 5: Schema unei celule solare tandem cu strat subțire pe bază de siliciu din componența (a) unui modul PV uzual, respectiv (b) unui modul BIPV colorat transparent

Schematic diagrams of a thin-film tandem microcrystalline silicon solar cell of (a) a regular solar module and (b) a transparent colored BIPV module.

The structure of a regular cell in tandem silicon thin-film solar modules is schematically shown in Fig. 5(a). In general, the thickness of the front and back glasses is about $3.2 \mathrm{~mm}$, the back reflector $0.5 \mathrm{~mm}$, the a-Si:H cell layer $300 \mathrm{~nm}$, the $\mu$-Si cell layer $1400 \mathrm{~nm}$, the back TCO $1500 \mathrm{~nm}$, and the front TCO $1800 \mathrm{~nm}$. In contrast, the structure of a see-through color BIPV module is schematically shown in Figure 5(b), where the back reflector in a regular cell will be dispelled for the purpose of see-through. In addition, a front reflector, named as the "reflective layer" in this work, will be added onto the front-glass substrate to reflect a certain part of spectrum of the incident sunlight and consequently make the solar panel appear with a specifically designed color. The thickness of the reflective layer is usually several tens of nanometers according to the specification of the designed color panels.

\section{Case study: evaluation of energetic parameters and aesthetic aspects}

\section{based on optical simulation of STHSC}

In general, thermalization losses for the STHSC device are reduced if most high energy photons are absorbed in the top subcell, and consequently, it is advantageous to absorb as much high energy photons as possible in the $\mathrm{Cu}_{2} \mathrm{O}$ absorber layer. Fig. 6(a) shows the calculated photo generated current versus thickness for the as-grown and annealed $\mathrm{Cu}_{2} \mathrm{O}$ layer under AM1.5G illumination. The calculation shows that an annealed $\mathrm{Cu}_{2} \mathrm{O}$ layer of $2 \mu \mathrm{m}$ thickness will generate about $10 \mathrm{~mA} / \mathrm{cm} 2$ of photocurrent. This corresponds to about $80 \%$ of the photocurrent that can be generated for an infinitely thick layer. Figure 6(a) also shows that the photo generated current is lower for the annealed $\mathrm{Cu}_{2} \mathrm{O}$ layer compared to the as-grown $\mathrm{Cu}_{2} \mathrm{O}$ layer, due to less grain-boundary scattering. Fig. 6(b) shows the calculated normalized reflectance, absorptance, and transmittance as a function of wavelength for the 
strat de AZO interior cu grosimea de $75 \mathrm{~nm}$ au fost implementate. Curbele arată că majoritatea fotonilor cu lungimea de undă mai mică de $600 \mathrm{~nm}$ sunt absorbiți în subcelula superioară de $\mathrm{ZnO} / \mathrm{Cu}_{2} \mathrm{O}$. Se constată că, pentru lungimile de undă mai mari din infraroșu, straturile AZO contribuie la absorbția parazitară, cauzată de absorbția purtătorilor liberi.

Grosimea tipică a stratului antireflectător $\operatorname{SiN}_{x}$ pentru o celulă solară convențională pe bază de c-Si este de aproximativ $80 \mathrm{~nm}$. Cu toate acestea, într-un dispozitiv STHSC, spectrul energetic al fotonilor care afectează subcelula inferioară c-Si este diferit în comparație cu cazul convențional, deoarece majoritatea fotonilor cu lungime de undă scurtă sunt absorbiţi în subcelula superioară. Fig. 7(a) prezintă intensitatea spectrală transmisă și absorbită pentru subcelula $\mathrm{ZnO} / \mathrm{Cu}_{2} \mathrm{O}$. Pentru ca stratul $\mathrm{SiN}_{\mathrm{x}}$ să acționeze ca o acoperire antireflexie eficientă, grosimea sa ar trebui să fie mărită faţă de grosimea standard pentru a permite schimbarea spectrului de fotoni către lungimi de undă mai lungi. Procentajele medii de reflectanță, absorptanță și transmitanță în funcție de grosimea stratului $\operatorname{SiN}_{x}$ sunt prezentate în Fig. 7(b). Calculele arată că cea mai mică reflectanță și cea mai mare transmitanță sunt obținute pentru o grosime de aproximativ $120 \mathrm{~nm}$ a stratului $\operatorname{SiN}_{\mathrm{x}}$. Prin creșterea grosimii acestuia de la $80 \mathrm{~nm}$ la $120 \mathrm{~nm}$, reflectanța totală a STHSC este redusă de la 12,7\% la 9,7\%.

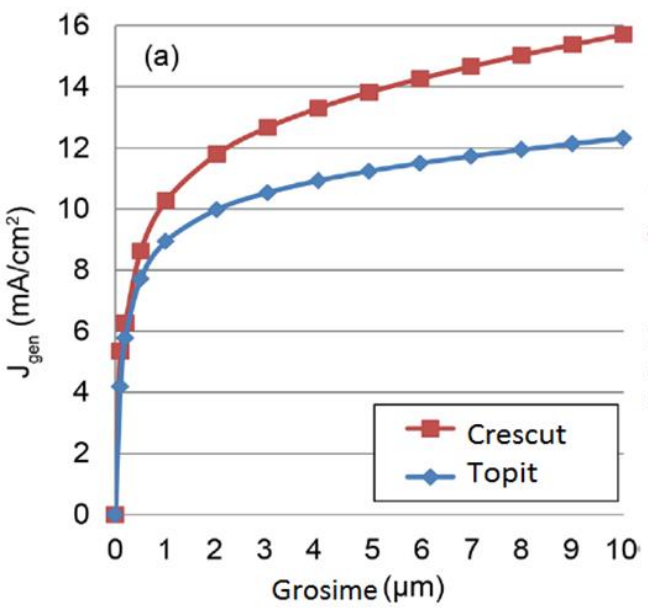

(a)

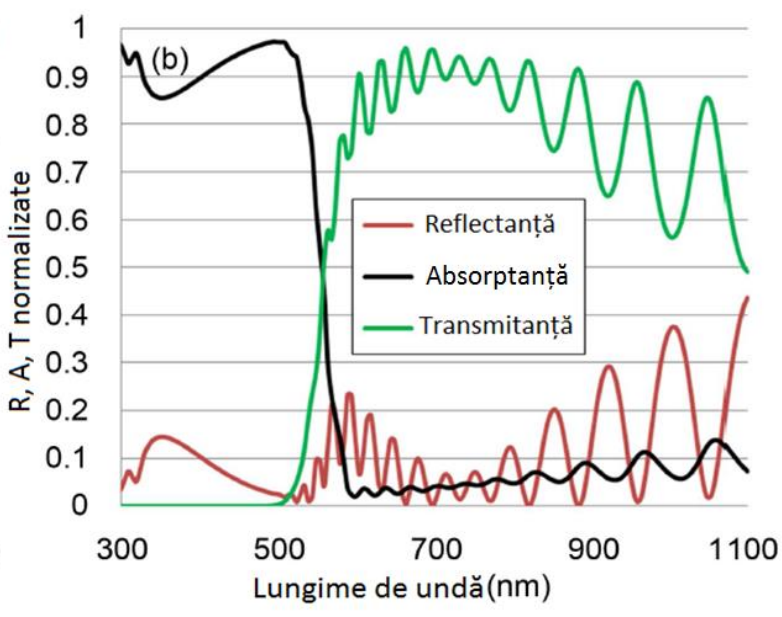

(b)

Fig. 6: (a) Curentul de fotogenerare calculat în funcție de grosime pentru pentru stratul subțire de $\mathrm{Cu}_{2} \mathrm{O}$ în condiții de iluminare AM1.5G; (b) Reflectanța (R), absorptanța(A) și transmitanța (T) normalizate în funcție de lungimea de undă pentru structura STHSC

(a) Calculated photogenerated current as a function of depth for the as-grown and annealed $\mathrm{Cu}_{2} \mathrm{O}$ thin film under AM1.5G illumination; (b) Normalized reflectance (R), absorptance (A), and transmittance (T) as a function of wavelength for the STHSC structure.

Pentru a obține performanțe energetice cât mai ridicate, principalul oxid metalic selectat pentru STHSC a fost $\mathrm{Cu}_{2} \mathrm{O}$. Panourile transparente fără stratul reflectător vor prezenta o culoare de la maro deschis la maro închis, în funcție de variaţiile grosimii peliculelor de siliciu microcristalin (Fig. 8), care au rol de absorbție a luminii. Folosind tehnologii bazate pe strat reflectător și inscripționare laser, module PV de diferite culori, precum albastru violet, albastru închis, albastru deschis, argintiu, auriu, portocaliu, roșu și cafeniu, ar putea fi proiectate cu succes (Fig. 9). 
device model depicted in Fig. 4. In this simulation, an $80 \mathrm{~nm}$ thick front AZO layer, a $2 \mu \mathrm{m}$ thick $\mathrm{Cu}_{2} \mathrm{O}$ layer, and a $75 \mathrm{~nm}$ thick bottom AZO layer were implemented in the model. The curves show that most of the photons with a wavelength below $600 \mathrm{~nm}$ are absorbed in the top $\mathrm{ZnO} / \mathrm{Cu}_{2} \mathrm{O}$ subcell. It can also be seen that in the long-wavelength range the AZO layers contribute to parasitic absorption, caused by free carrier absorption.

The typical thickness of a $\mathrm{SiN}_{\mathrm{x}}$ anti-reflection coating for a conventional c-Si solar cell is approximately $80 \mathrm{~nm}$. However, in a STHSC device the energy spectrum of photons impinging on the c-Si bottom subcell is different compared to the conventional case since most short-wavelength photons are absorbed in the top subcell. Fig. 7(a) shows the transmitted and absorbed spectral intensity for the $\mathrm{ZnO} / \mathrm{Cu}_{2} \mathrm{O}$ subcell. In order for the $\mathrm{SiNx}$ layer to act as an effective antireflection coating, its thickness should be increased from the standard thickness to accommodate the shift of the photon spectrum towards longer wavelengths. The average percentage reflectance, absorptance, and transmittance as a function of thickness for the $\mathrm{SiN}_{\mathrm{x}}$ layer are shown in Fig. 7(b). The calculations show that the lowest reflectance and highest transmittance are obtained for a thickness of approximately $120 \mathrm{~nm}$ for the $\mathrm{SiN}_{\mathrm{x}}$ layer. By increasing the thickness of the $\mathrm{SiN}_{\mathrm{x}}$ layer from $80 \mathrm{~nm}$ to $120 \mathrm{~nm}$, the total reflectance for the STHSC device is reduced from $12.7 \%$ to $9.7 \%$.

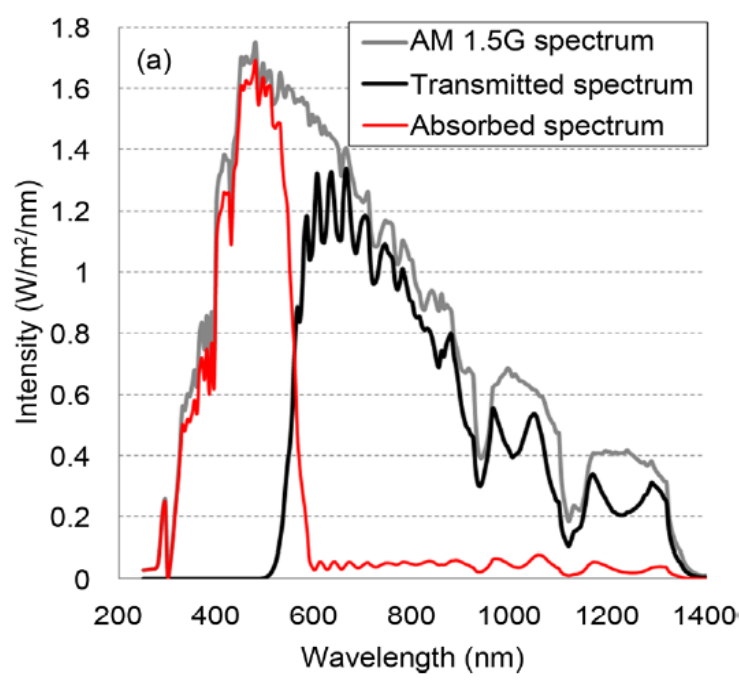

(a)

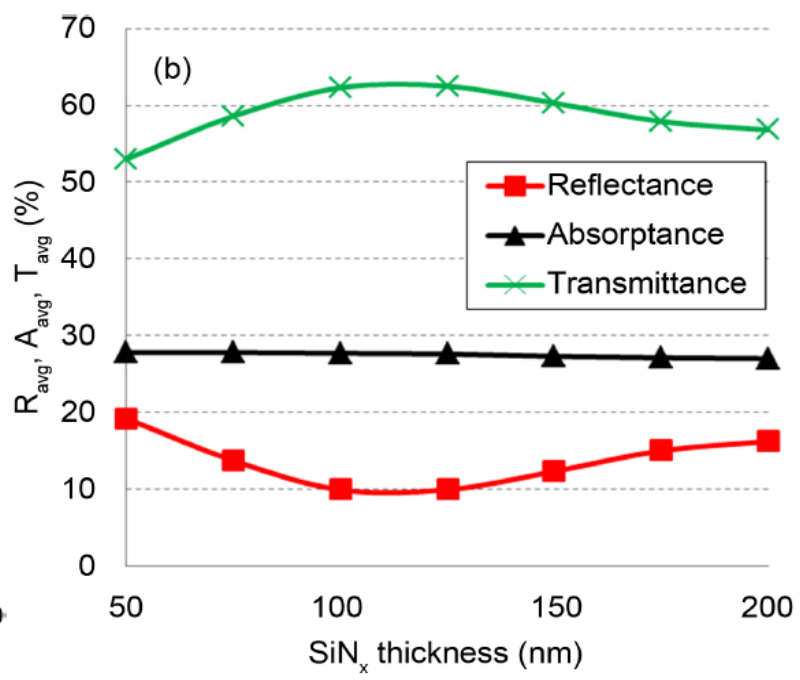

(b)

Fig. 7: (a) Intensitatea spectrală absorbită și transmisă pentru subcelula $\mathrm{ZnO} / \mathrm{Cu} 2 \mathrm{O}$ în condiții de iluminare AM1.5G; (b) Procentajul mediu al reflectanței (Ravg), absorptanței (Aavg), și transmitanței (Tavg) în subcelula $\mathrm{ZnO} / \mathrm{Cu} 2 \mathrm{O}$ în functie de grosime pentru stratul $\mathrm{SiNx}$

(a) Absorbed and transmitted spectral intensity for the $\mathrm{ZnO} / \mathrm{Cu}_{2} \mathrm{O}$ subcell along with the $\mathrm{AM} 1.5 \mathrm{G}$ spectrum; (b) Average percentage reflectance $\left(\mathrm{R}_{\text {avg }}\right)$, absorptance $\left(\mathrm{A}_{\text {avg }}\right)$, and transmittance $\left(\mathrm{T}_{\text {avg }}\right)$ for the $\mathrm{ZnO} / \mathrm{Cu}_{2} \mathrm{O}$ subcell as a function of thickness for the $\mathrm{SiN}_{\mathrm{x}}$ layer.

To establish energetic performances as high as possible, the main metal oxide selected for STHSC was $\mathrm{Cu}_{2} \mathrm{O}$. The see-through panels without the reflective layer will appear from light brown to dark brown according to the variations of the thickness of the microcrystalline silicon light-absorbing films, as shown in Fig. 8. With the technologies of the reflective layer and laser scribing, eight different colors of purple, dark blue, light blue, silver, gold, orange, red, and coffee tandem microcrystalline silicon thin-film see-through solar modules could be successfully designed, as in Fig. 9. 


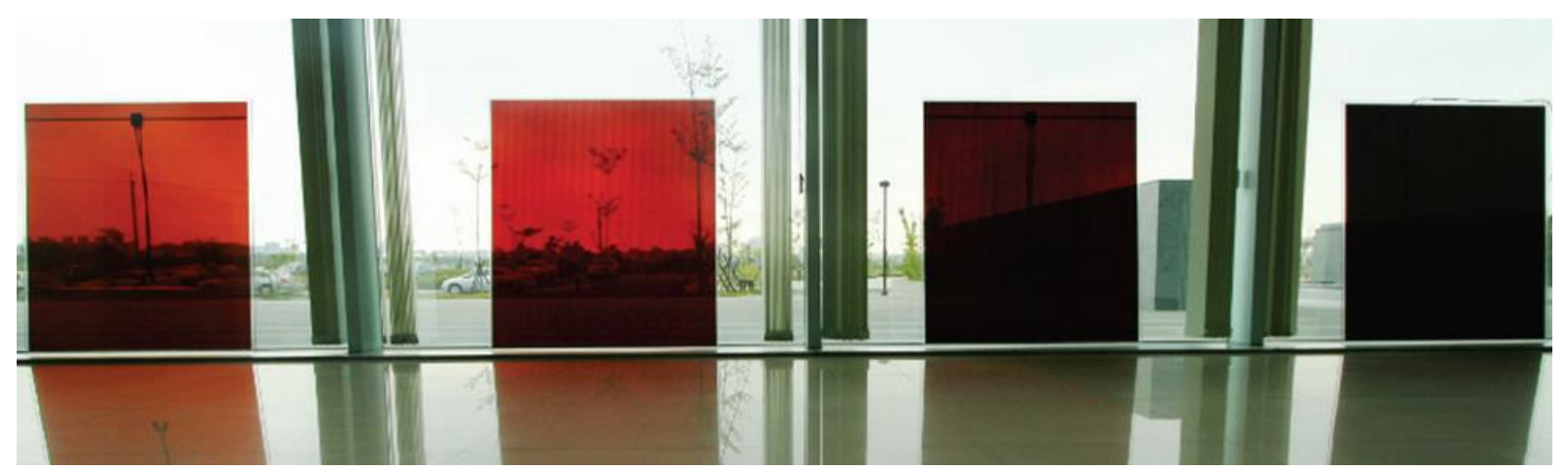

Fig.8: Module BIPV transparente cu STHSC de diferite grosimi, fără straturi reflectătoare

STHSC see-through BIPV modules of different film thicknesses and without the reflective layers

\section{Concluzii și perspective}

În cadrul acestui studiu au fost conturate următoarele aspecte:

- proiectarea și dezvoltarea sistemelor BIPV, pe baza modelării electro-optice, a permis introducerea aspectelor legate de culoare;

- utilizarea de către arhitecți a sistemelor BIPV colorate a evidențiat atât performanțele energetice, cât și cele estetice ale acestor dispozitive.

Modelarea optică prezentată în această lucrare s-a axat pe calcularea curbelor spectrale ale reflectanței, absorptanței și transmitanței pentru diferite grosimi ale straturilor subțiri ce constituie subcelula $\mathrm{ZnO} / \mathrm{Cu}_{2} \mathrm{O}$ a unei celule solare tandem cu heterojuncțione pe bază de siliciu. S-a pus în evidență faptul că modulele solare colorate și transparente pe bază de siliciu policristalin pot fi proiectate și dezvoltate cu succes pentru aplicații ale sistemelor fotovoltaice integrate în clădiri.

A fost sintezată concepția în care caracterizarea optică a componentelor celulelor solare dedicate poate fi combinată cu modelarea optică și de culoare, ce permite evaluarea proprietăților energetice, optice și estetice ale celulelor solare.

Scopul lucrării a fost încurajarea introducerii pe scară largă a sistemelor BIPV colorate pe piața construcțiilor, perspectivele de implementare ale acestui studiu fiind următoarele:

- testarea și acceptarea celulelor solare studiate (DSSC și STHSC) din punctul de vedere al standardelor de construcție și al stabilității;

- progresul pieței BIPV datorită integrării de către arhitecți a acestor concepte în soluțiile tipice pentru clădirile moderne.

Produsele BIPV existente pe piață la ora actuală oferă o gamă largă de integrare a sistemelor fotovoltaice în clădiri. Cercetarea și dezvoltarea continuă în cadrul materialelor și tehnologiilor PV și BIPV vor oferi soluții din ce în ce mai bune în anii următori, în ceea ce privește eficiența crescută a celulelor solare, aspectele de mediu, costurile de producție reduse şi integrarea îmbunătățită în clădiri.

\section{Acknowledgments}

Aceasta lucrare a fost finantata de Unitatea Executiva pentru Finantarea Invatamantului Superior, a Cercetarii, Dezvoltarii si Inovarii (CNCS-UEFISCDI), prin Proiectul M-ERA.NET, SOLHET, Contract Nr. 34/2016, FI 541602. 


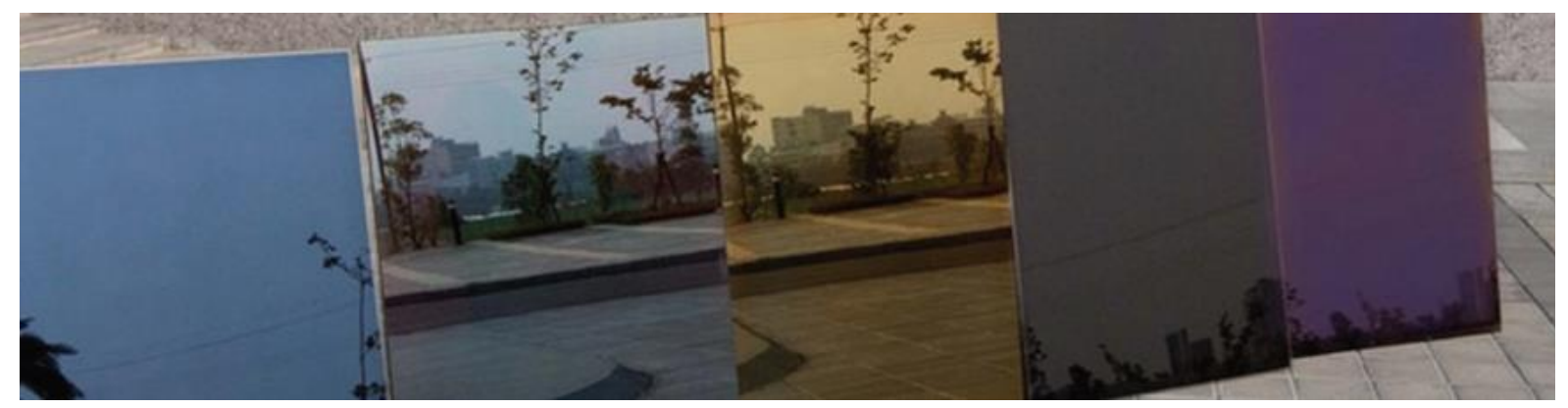

Fig. 9: Module BIPV transparente cu STHSC de diferite culori

STHSC see-through BIPV modules of different colors

\section{Conclusions and prospects}

The main conclusions of this study are as follows:

- design and development of BIPV systems based on optical modeling, where color-related aspects were introduced;

- use of these BIPV systems by architects, taking into account the enhancement of both energetic and aesthetic performances.

The optical analysis presented in this work focused on calculating the spectral curves for reflectance, absorptance, and transmittance for different thicknesses of the thin film layers constituting the $\mathrm{ZnO} / \mathrm{Cu}_{2} \mathrm{O}$ subcell of a silicon-based tandem heterojunction solar cell. In this work it was shown that tandem crystalline silicon thin-film see-through color solar modules can be successfully designed and developed for building-integrated photovoltaic applications.

An overview was given on how optical characterization of dedicated solar cell components can be combined with optical and color modeling to simultaneously predict and evaluate the energetic, optical and aesthetic properties of the solar cells.

The purpose of this work was the introduction of colored BIPV systems in the building market on a larger scale. Hence, the prospects to implement this study are the following: - testing and accepting the studied solar cells (DSSC and STHSC) by construction standards and stability points of view;

- the progress of BIPV market due to integration by the architects of these concepts into the typical solutions for modern buildings.

State-of-the-art building integrated photovoltaic (BIPV) products existing on the market today offer a wide range of integration of photovoltaic (PV) systems into buildings. Continued research and development within both PV and BIPV materials and technologies will yield better and better BIPV solutions in the years to come, with respect to increased solar cell efficiency, environmental aspects, reduced production costs and improved building integration.

\section{Acknowledgments}

This work was supported by the Romanian National Authority for Scientific Research through the CNCS-UEFISCDI under Project M-ERA.NET, SOLHET, Contract No. 34/2016, FI 541602. 


\section{Referinţe/References}

Fara, L., \&Yamaguchi, M. (2013) Advanced Solar Cell Materials, Technology, Modeling, and Simulation. Hershey: IGI Global Publishing House

Jelle B. P. (2016) Building Integrated Photovoltaics: A Concise Description of the Current State of the Art and Possible Research Pathways. Energies 9(1), 21

Halme J., Kemppainen, E., Asghar, I., Colodrero, S., Wolf, B., Miguez, H., \& Lund, P.(2012). Optimizing transparency and performance of semitransparent dye - sensitized solar cells (DSC) for building façades. Annual Energy Forum in Bressanone, Italy

Yoon, S., Tak, S., Kim, J., Jun, Y., Kang, K., \& Park, J. (2011). Application of transparent dyesensitized solar cells to building integrated photovoltaic systems. Build. Environ., 46(10), 1899-1904.

Halme, J., Vahermaa, P., Miettunen, K., \& Lund, P. (2010). Device Physics of Dye Solar Cells. Adv. Mater., 22(35).

Toivola, M., Halme, J., Miettunen, K., Aitola, K., \& Lund, P. D. (2009). Nanostructured dye solar cells on flexible substrates-Review. Int. J. Energy Res., 33: 1145-1160.

Tagliaferro, R., Colonna, D., Brown, T. M., Reale, A., \& Carlo, A. D. (2013). Interplay between transparency and efficiency in dye sensitized solar cells. Optics Express, 21(3), 3235 .

Tsai, Chin-Yi \& Tsai, Chin-Yao, (2014). Development of Tandem Amorphous/Microcrystalline Silicon Thin-Film Large-Area See-Through Color Solar Panels with Reflective Layer and 4-Step Laser Scribing for Building-Integrated Photovoltaic Applications. J. Nanomater., 2014, 809261.

Nordseth, Ø., Kumar, R., Bergum, K., Fara, L., Foss, S., Haug, H., Drăgan, F., Crăciunescu, D., Sterian, P., Chilibon, I., Vasiliu, C., Baschir, L., Savastru, D., Monakhov, E., \& Svensson, B. (2017). Optical Analysis of a $\mathrm{ZnO} / \mathrm{Cu}_{2} \mathrm{O}$ Subcell in a Silicon-Based Tandem Heterojunction Solar Cell. Green and Sustainable Chemistry, 7, 57-69.

Grätzel, M. (1991). The artificial leaf, molecular photovoltaics achieve efficient generation of electricity from sunlight. Coord. Chem. Rev., 111, 167-174

Svensson, B.G., Pearton, S.J. and Jagadish, C. (2013). Oxide Semiconductors, Semiconductors and Semimetals. Vol. 88, Amsterdam: Elsevier \& Academic Press

\section{Referinţe web/Web references}

Sinovoltaics http://sinovoltaics.com/learning-center/solar-cells/colored-solar-cellsspecialities-and-limitations/

ThEP http://thep-center.org/src2/views/network-academic-news_en.php?news_id=16 